\title{
Reconciling the Principled Approach to Hearsay with the Rule of $\mathrm{Law}^{\dagger}$
}

\author{
Andrew Botterell
}

\section{INTRODUCTION}

My goal in this paper is to argue that the principled approach to hearsay is consistent with the rule of law. My argument has three main parts. In the first part I contrast two conceptions of the rule of law, one that views it in an instrumental manner and another that views it primarily in normative terms. I argue that the normative conception is preferable. In the second part I describe and discuss the principled approach to hearsay. In the third part, I link the first part to the second by arguing that if the rule of law expresses certain normative ideals, then there is no tension between the principled approach to hearsay and the rule of law.

That said, the connection between the three parts of the argument is complicated. At a very general level, I want to argue that both the rule of law and the principled approach to hearsay express certain normative principles or ideals. The rule of law describes an abstract moral relation that holds between individuals by virtue of those individuals occupying certain legally defined roles. The principled approach to hearsay requires that judges adopt a certain ethical stance towards trial participants, a stance that manifests an attitude of respect and concern for the participants' interests. In my view, it is these normative considerations that make it possible to reconcile the rule of law with the principled approach to hearsay. So my argument depends on adopting particular interpretations of both the rule of law and the principled approach to hearsay. However, articulating and

$\dagger \quad$ The ideas for this paper emerged from a graduate seminar in criminal law theory that I taught with Dennis Klimchuk in the Fall of 2012. For extremely helpful comments and advice on previous versions of this paper I would like to thank Graham Mayeda and an anonymous reviewer for this journal. I would also like to thank Justice Charron for allowing me to clerk for her, and for showing me what it means to occupy the role of a judge.

* Andrew Botterell is an Associate Professor in the Department of Philosophy and the Faculty of Law at the University of Western Ontario. He clerked for Justice Charron during the 2006-2007 Term. 
defending these interpretations takes some work. With respect to the rule of law, I do this by contrasting Joseph Raz's instrumental conception of the rule of law with Lon Fuller's interpretation, and then moving from Fuller's interpretation to Michael Oakeshott's conception of the rule of law as an abstract form of moral association. With respect to the principled approach to hearsay, I reveal its normative dimension by appealing to a distinction between internal and external perspectives on the criminal trial process. This yields the conclusion that the principled approach to hearsay expresses the same kinds of normative considerations that animate Oakeshott's conception of the rule of law and thus, that the principled approach to hearsay is consistent with the rule of law.

My argument is developed in part in response to Colin Tapper's recent argument that, because it results in uncertainty and unpredictability, and because it leaves too much power in the hands of judges, the principled approach to hearsay is inconsistent with the rule of law. ${ }^{1}$ Tapper's argument fails, I argue, because it misrepresents the content of the principled approach but more importantly, because it relies on a questionable conception of the rule of law. Responding to Tapper's criticisms of the principled approach to hearsay will enable me to flesh out these admittedly sketchy references to normative ideals, ethical stances and forms of moral association. That is the outline of my argument.

Before continuing, however, it pays to ask: Why bother trying to reconcile the principled approach to hearsay with the rule of law? What hangs on the resolution of this issue? Let me make two observations. First, the principled approach to hearsay marks an important development in the Canadian law of evidence. By focusing on the indicia of necessity and reliability, the principled approach to hearsay unifies what initially appear to be disparate rules and exceptions, and articulates a conception of the broader principles that underlie the hearsay rule. Time spent understanding the principles that ground the principled approach to hearsay is therefore time well spent. Second, whatever else it is, the rule of law is a virtue of a legal system. Although some, such as Joseph Raz, have questioned the scope and centrality of this virtue, virtually everybody agrees that a legal system or rule that offends the rule of law is for that reason defective. So demonstrating that the principled approach to hearsay is consistent with the rule of law goes some way towards showing that the principled approach reflects fundamental principles of justice

Colin Tapper, "The Law of Evidence and the Rule of Law" (2009) 68 Cambridge L.J. 67 [hereinafter "Tapper"]. 
and legality. In short, if one is attracted to the principled approach to hearsay - as I am - it would surely be a good thing to show that it is consistent with the rule of law, a concept that reflects core legal virtues. These considerations are the impetus for the discussion that follows.

\section{TRUTH AND NORMATIVITY IN THE CRIMINAL TRIAL}

Although my eventual goal is to discuss the relationship between the principled approach to hearsay and the rule of law, let me begin by briefly considering the purpose of the criminal trial.

It is often said that the criminal trial is primarily an epistemic enterprise that is designed to determine the truth. For example, Cory J. claimed that " $\mathrm{t}] \mathrm{h}$ he ultimate aim of any trial, criminal or civil, must be to seek and to ascertain the truth". ${ }^{2}$ Justice Lewis Powell, dissenting in Bullington v. Missouri, said the following:

Underlying the question of guilt or innocence is an objective truth: the defendant, in fact, did or did not commit the acts constituting the crime charged. From the time the accused is first suspected to the time the decision on guilt or innocence is made, our criminal justice system is designed to enable the trier of fact to discover the truth according to law. ${ }^{3}$

And in his important book, Truth, Error, and Criminal Law, Larry Laudan argues that "a criminal trial is first and foremost an epistemic engine, a tool for ferreting out the truth from what will often initially be a confusing array of clues and indicators". ${ }^{4}$ According to this picture, the point of the criminal trial is primarily epistemological: to determine what actually happened.

This is a familiar picture. But while there is much to recommend it, it nonetheless misses something important about the criminal trial in particular and the criminal justice system in general. What it misses is that the criminal trial is a normative enterprise, the primary aim of which is to determine whether the punishment of the accused is justified, whether the coercive force of the state has been rightly brought to bear on a particular accused. This is what I mean when I say that the point of the criminal trial is normative. The criminal trial is not designed primarily to determine what

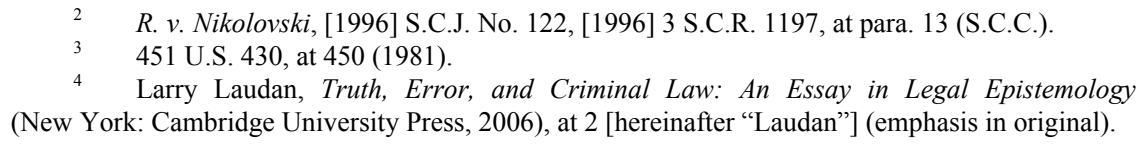


has happened, although it sometimes does that; nor is it designed to simply punish those who do wrong, although it sometimes does that too. Rather, the criminal trial is designed to impose punishment on wrongdoers, and to do so in a manner that is consistent with principles of justice. The point of the criminal trial, in short, is to reach a just verdict.

That the criminal trial is primarily a normative enterprise rather than a truth-seeking one can be seen by considering the following. First, we sometimes know what happened even before a trial begins. This suggests that the point of the trial cannot be to determine the truth since in such cases the truth is already known. Second, there are cases where we do not know what happened, but a determination of guilt is justified nonetheless. Suppose, for example, that $\mathrm{A}$ and $\mathrm{B}$ engage in a gunfight on a busy street, that $\mathrm{C}$ is shot and killed, and that at trial it is impossible to determine which of A or B fired the shot that killed C. It might be appropriate nonetheless to find both A and $\mathrm{B}$ are guilty of murder on the grounds that they intentionally engaged in a mutual gunfight, and so are responsible in law for the unlawful actions of each other. ${ }^{5}$ If the principal point of the criminal trial is to find out the truth, this sort of situation would make little sense, for how could a verdict be reached when there is still a question about what actually occurred?

I do not mean to suggest that rules of evidence do not have a truthseeking component or function. Somebody attracted to an epistemic view of the criminal trial could certainly agree that the criminal trial includes a normative component while also maintaining that that component cannot be satisfied unless it is known beyond a reasonable doubt what actually happened. Recall Powell J.'s remark in Bullington v. Missouri. What he in fact says is that the "criminal justice system is designed to enable the trier of fact to discover the truth according to law." The qualification "according to law" is important since it indicates that it may not be truth simpliciter that is of interest. For example, we may not know as a matter of fact whether A or B fired the shot that killed C; but we may know all the same that both A and B are as a matter of law guilty of murder. Still, while a trial can have both normative and truth-seeking elements, its normative function is primary. This is significant, since it means that epistemic justifications of the rules of evidence should be subordinated to normative justifications of those same rules. Even if a particular rule of evidence is truth-conducive, and so justified from an epistemic perspective, it may be unjustified from a normative perspective if it fails to

5 See, e.g., R. v. R. (J.S.), [2008] O.J. No. 5505, 2008 ONCA 544 (Ont. C.A.). 
safeguard certain rights of the accused, or makes it less likely that any verdict reached and punishment imposed will be morally justified. ${ }^{6}$

\section{EXTERNAL AND INTERNAL PERSPECTIVES ON THE CRIMINAL TRIAL}

In A Philosophy of Evidence Law, Ho Hock Lai usefully distinguishes two perspectives that one might adopt with respect to the trial process. ${ }^{7}$ Ho calls the first perspective the external perspective of the system engineer; for simplicity, I will call it the external perspective. According to this perspective, "the trial should be regulated such that it will best achieve its goals", chief among which "is the discovery of truth in disputes of fact". ${ }^{8}$ From the external perspective, individual rules of evidence and procedure should be evaluated based on their tendency to determine the truth; equivalently, the design of a legal system should be guided by the principle that rules should be selected based on their tendency to decrease the rate of errors. Thus, from the point of view of the external perspective, rules of evidence and procedure will be well designed if they tend to "ferret out" the truth. The external perspective is the perspective adopted by Laudan in Truth, Error, and Criminal Law. This can be seen in his remark that the central question for legal epistemology is whether trial systems that "purport to be seeking the truth are well engineered to lead to true beliefs about the world".

Ho contrasts the external perspective with what he calls the internal perspective of the fact-finder as a moral agent; for simplicity, I will call it the internal perspective. The core insight of the internal perspective is that the perspective that ought to be adopted when thinking about the trial process in particular, and the legal system in general, is one that views judges as role-players within a system and procedural and evidential rules

For a similar sort of argument, see Hamish Stewart, "The Law of Evidence and the Protection of Rights" [hereinafter "Stewart"] in James Stribopoulos \& François Tanguay-Renaud, eds., Rethinking Criminal Law Theory (Oxford: Hart Publishing, 2012) 177.

Ho Hock Lai, A Philosophy of Evidence Law: Justice in the Search for Truth (Oxford: Oxford University Press, 2008) [hereinafter "Ho"]. To be precise, Ho discusses two perspectives that one might adopt with respect to the fact-finding process. As it is understood by Ho, however, the fact-finding process includes what we would ordinarily call matters of law in addition to matters of fact - for example, a judge's decision to exclude certain evidence on the grounds that it is hearsay, or on the grounds that it would unduly prejudice the deliberations of the jury, is treated by Ho as part of the fact-finding process.

$8 \quad I d$., at $46-47$.

9 Laudan, supra, note 4, at 2. 
as normative. This is in contrast to the view that judges are disinterested epistemic engineers viewing the system from the outside, and that procedural and evidential rules are directed towards epistemic ends. As Ho puts it:

Instead of assessing evidentiary rules functionally, as means of achieving specified ends, they are evaluated modally, as constituting features of a rational form of moral engagement between the court and the persons brought before it. This kind of evaluation is conceptual in nature and is founded on normative arguments; it is not contingent on the validity of empirical assumptions connecting means and ends. ${ }^{10}$

From this perspective, the worth of a particular rule of evidence is not solely a function of its tendency to contribute to epistemic goals. Rather, rules of evidence must be assessed in terms of their role in a system that is designed to justify the state's imposition of punishment on an accused. Says Ho, the "rightness of a rule is not determined by the consequences that flow from its application but is inherent in the values it expresses" where those values are intrinsic to the rule itself. ${ }^{11}$ Thus, even if a given evidential rule has detrimental epistemic consequences, it might nonetheless be justified if it expresses a value that is integral to the trial process. As Ho eloquently puts it, according to the internal perspective "[t]he court must not only find truth in order to reach a just outcome, it must also do justice in the course of ascertaining the truth". ${ }^{12}$

\section{THE RULE OF LAW}

To this point I have argued that the trial process is best viewed in normative rather than epistemological terms, and I have appealed to Ho Hock Lai's distinction between external and internal perspectives on that process. What I would like to do now is turn to a discussion of the rule of law. I will contrast two conceptions of the rule of law, a normative conception and an instrumental one, and I will argue that the normative conception of the rule of law is to be preferred. I will do this by appealing to a picture of the rule of law found in the works of Lon Fuller and Michael Oakeshott. I will suggest that the best conception of the rule of law is one that views it as a moral relation that holds between persons in

\footnotetext{
Ho, supra, note 7 , at 48

Id. Id., at 49 .
} 
virtue of those individuals occupying certain roles. This conception, I claim, is superior to an instrumental conception for several reasons. First, it accounts for the very plausible idea that the rule of law constrains the actions of individuals because of the role occupied by those individuals. For example, a judge acts contrary to the rule of law when her ostensibly judicial pronouncements and decisions go beyond the scope of the authority conferred on her by occupying the role of judge. And second, the moral relation conception of the rule of law is superior to the instrumental conception because it articulates a more general vision of the rule of law. It is general in that it is one that applies not only to judges, politicians and legislators, but also to private citizens in their interactions with other private actors. It therefore makes sense of the often-overlooked fact that the rule of law has both public law and private law dimensions. ${ }^{13}$

That said, it is notoriously difficult to say what the rule of law is. This is because different people mean many different things by it. For example, some think that the rule of law is either trivial or false. For if the rule of law means that government must be by law and not by human beings, then on one reading this claim is false, since government must be by both law and human beings. On another reading, however, it is trivial, since by definition a decree or command that is not authorized by law is not a decree or command of a government acting as a government, and so cannot constitute a law at all. ${ }^{14}$ Others seem to think that the rule of law is all the law that we need. Here I have in mind T.R.S. Allen, who argues that from the rule of law can be derived most (all?) of the normative and structural principles characteristic of a liberal democratic state, including the separation of powers and the principle of formal equality. ${ }^{15}$

Despite this lack of consensus regarding the structure and content of the rule of law, however, some general comments can be made. Commentators tend to draw (at least) a four-fold distinction: between formal and substantive versions of the rule of law on the one hand, and between

13 For discussion of the importance of the rule of law in private law, see the papers collected in Lisa Austin \& Dennis Klimchuk, eds., The Rule of Law and Private Law (Oxford University Press, forthcoming).

${ }_{14}$ See "The Rule of Law and Its Virtue" in Joseph Raz, The Authority of Law: Essays on Law and Morality, 2d ed. (Oxford: Oxford University Press, 2009) 210, at 212 [hereinafter "Raz"].

15 For example, T.R.S. Allan, Constitutional Justice: A Liberal Theory of the Rule of Law (Oxford: Oxford University Press, 2003). See also T.R.S. Allan, "The Rule of Law as Liberal Justice" (2006) 56 U.T.L.J. 283; and "Dworkin and Dicey: The Rule of Law as Integrity" (1988) 8 Oxford J. Legal Stud. 266. 
thick and thin formulations on the other. ${ }^{16}$ Formal versions of the rule of law view the rule of law in procedural terms, insisting that the rule of law is an instrument by and through which governments rule. Substantive versions of the rule of law, on the other hand, view the rule of law as embodying rights of one sort or another: personal and property rights, democratic rights, rights to dignity, substantive equality and so on. Thin substantive versions of the rule of law tend to include only individual rights, while thick - or thicker — versions include democratic and dignity rights. Conversely, thin formal versions of the rule of law embody minimal procedural rights, while thick - or thicker - versions require more restrictions on the sort of laws, or rules, by and through which governments can rule. Paul Craig summarizes this general picture in the following passage:

Formal conceptions of the rule of law address the manner in which the law was promulgated ...; the clarity of the ensuing norm ...; and the temporal dimension of the enacted norm ... Formal conceptions of the rule of law do not however seek to pass judgment upon the actual content of the law itself ... Those who espouse substantive conception of the rule of law seek to go beyond this. They accept that the rule of law has the formal attributes mentioned above, but they wish to take the doctrine further. Certain substantive rights are said to be based on, or derived, form the rule of law. The concept is used as the foundation for these rights, which are then used to distinguish between "good" laws, which comply with such rights, and "bad" laws which do not. ${ }^{17}$

A relatively thin and formal conception of the rule of law can be found in the work of Joseph Raz. In "The Rule of Law and its Virtue", Raz argues that while the rule of law is a virtue of legal systems, "the rule of law is just one of the virtues which our legal system may possess and by which it is to be judged." ${ }^{\prime 18}$ As he goes on to argue:

Regarding the rule of law as the inherent or specific virtue of law is a result of an instrumental conception of law. The law is not just a fact of life. It is a form of social organization which should be used properly for the proper ends. It is a tool in the hands of men differing from many

16 For a more detailed discussion, see Brian Tamanaha, On the Rule of Law: History, Politics, Theory (Cambridge: Cambridge University Press, 2004). For criticism of this way of sketching the logical geography, see Peter Rijpkema, "The Rule of Law Beyond Thick and Thin" (2013) 32 Law \& Phil. 793.

Paul Craig, "Formal and Substantive Conceptions of the Rule of Law: An Analytical Framework" (1997) 21 P.L. 467, at 467.

18 Raz, supra, note 14 , at 210. 
others in being versatile and capable of being used for a large variety of proper purposes. As with some other tools, machines, and instruments a thing is not of the kind unless it has at least some ability to perform its function. A knife is not a knife unless it has some ability to cut. The law to be law must be capable of guiding behavior, however inefficiently. Like other instruments, the law has a specific virtue which is morally neutral in being neutral as to the end to which the instrument is put. It is the virtue of efficiency; the virtue of the instrument as an instrument. For the law this virtue is the rule of law. Thus the rule of law is an inherent virtue of the law but not a moral virtue as such. ${ }^{19}$

This conception of the rule of law is instrumental and morally neutral; or in the terminology introduced above, it is formal and thin.

In contrast, Ronald Dworkin endorses a substantive and thick conception of the rule of law. As he says in articulating the so-called "rights conception" of the rule of law, this conception

assumes that citizens have moral rights and duties with respect to one another, and political rights against the state as a whole. It insists that these moral and political rights be recognized in positive law, so that they may be enforced upon the demand of individual citizens through courts or other judicial institutions of the familiar type, so far as this is practicable. The rule of law on this conception is the idea of rule by an accurate public conception of individual rights. It does not distinguish, as the [formal] conception does, between the rule of law and substantive justice; on the contrary it requires, as part of the ideal of law, that the rules ... capture and enforce moral rights. ${ }^{20}$

The rights conception of the rule of law is substantive because it requires the rule of law to "capture and enforce moral rights". It is thick because the rights that the rule of law seeks to capture and enforce are robust.

But another conception of the rule of law is available, one that appears to combine the formal with the substantive. I have in mind Lon Fuller's conception of the rule of law as expressed in The Morality of Law. $^{21}$ It is natural to interpret Fuller as articulating a formal conception of the rule of law, given that his eight ways make law appear to be procedural in nature. ${ }^{22}$

$19 \quad$ Id., at 226

20 Ronald Dworkin, "Political Judges and the Rule of Law", in A Matter of Principle (Cambridge, MA: Harvard University Press, 1985), at 11-12 (emphasis in original).

21 Lon Fuller, The Morality of Law (New Haven: Yale University Press, 1964) [hereinafter "Fuller"].

22 Fuller's eight principles are as follows: (1) Generality — legal systems should achieve general rules; (2) Promulgation — laws should be published; (3) Prospectivity — laws should be 
For example, the claim that laws must be public, non-retroactive and general suggests that what matters from the perspective of the rule of law, or the principle of legality, is the form that the laws take, rather than the content that they have. However, Fuller is also clear that in his view that these principles constitute an internal or inner morality of law. ${ }^{23}$ To be sure Fuller's argument is interesting in its own right, and much has been written about it. ${ }^{24}$ However, my interest in it has to do with the fact that in my view it leads naturally to Oakeshott's conception of the rule of law as a form of moral association. Thus, in the next few pages I will sketch a way of thinking about Fuller's view of the relationship between law and morality that dovetails with Oakeshott's conception of the rule of law. This is important for my argument, first, because Oakeshott's conception of the rule of law represents a sophisticated and attractive normative conception of the rule of law, and second, because it is the conception of the rule of law that I will appeal to when criticizing Tapper's objection to the principled approach to hearsay. In short, from Fuller we get a novel account of the relationship between law and morality; that account leads naturally to Oakeshott's normative conception of the rule of law; and Oakeshott's normative conception is central to my argument that the principled approach to hearsay is compatible with the rule of law.

So let me turn, all too briefly, to Fuller and Oakeshott. The first thing to emphasize when considering Fuller's views on the relationship between law and morality is that law makes possible certain forms of moral interaction, ${ }^{25}$ and that the forms of moral interaction made possible by principles of legality - i.e., the rule of law - apply to individuals by

prospective rather than retrospective; (4) Clarity - laws should be clearly stated and understandable; (5) Compatibility — laws should be compatible with one another; (6) Possibility laws should not command the impossible; (7) Constancy - laws should not be subject to constant change; and (8) Congruence - consistency between the law as declared and the law as administered.

23 Fuller, supra, note 21, at 153.

24 For extended discussion of Fuller's views on the rule of law and the inner morality of the law, see Alan R. Mabe, "The Relationship of Law and Morality" (1974) 12 Southern Journal of Philosophy 71 and "Fuller and the Internal Morality of Law" (1975) 13 Southern Journal of Philosophy 515; Christine Pierce, "Mabe on Fuller" (1975) 13 Southern Journal of Philosophy 511; Peter Nicholson, "The Internal Morality of Law: Fuller and His Critics" (1974) 84 Ethics 307; and Frederick Schauer, "Fuller's Internal Point of View" (1994) 13 Law \& Phil. 285.

${ }_{25}$ As Fuller puts it, "[t]o live the good life requires ... the support of firm base lines for human interaction, something that — in a modern society at least — only a sound legal system can supply". See Fuller, supra, note 21, at 205. Thus, while Fuller talks in The Morality of Law of the morality that makes law possible, it is perhaps more appropriate to think of Fuller as describing the law that makes morality possible. 
virtue of those individuals occupying certain roles or offices: "If respect for the principles of legality is essential to produce [a legal] system, then certainly it does not seem absurd to suggest that these principles constitute a special morality of role attaching to the office of law-maker and law-administrator." 26 This is Fuller's first idea: the rule of law is or expresses a morality of role.

Fuller then draws a distinction between two kinds of social ordering: managerial direction and law, a distinction that I will suggest is also found in Oakeshott's discussion of the rule of law. Says Fuller:

A general and summary statement of the distinction between the two forms of social ordering might run somewhat as follows: The directives issued in a managerial context are applied by the subordinate in order to serve a purpose set by his superior ... The rules of a legal system, on the other hand, normally serve the primary purpose of setting the citizen's relations with other citizens and only in a collateral manner his relations with the seat of authority from which the rules proceed. ${ }^{27}$

That is, legal rules are designed in the first instance to structure the relationships between persons qua citizens. Consequently, for Fuller "law is not, like management, a matter of directing other persons how to accomplish tasks set by a superior, but is basically a matter of providing the citizenry with a sound and stable framework for their interactions with one another". ${ }^{28}$ On this view, the rule of law has no purpose apart from "setting the citizen's relations with other citizens". Which particular interactions individual citizens engage in are up to them: they can get married, buy a house or drive a car. With respect to these ends the law is indifferent. When citizens do act, however, the principle of legality requires them to act in a way that is consistent with the framework of relations that is constituted by the law.

In my view, Fuller's account of the rule of law leads naturally to Oakeshott. Like Fuller, Oakeshott also drew a distinction between two forms of social ordering, which he called telocracy and nomocracy. Roughly, telocracy describes a form of government primarily concerned with fostering particular ends, while nomocracy describes a form of government primarily concerned with promulgating particular rules. Thus, for Oakeshott telocracy meant the proper business of government

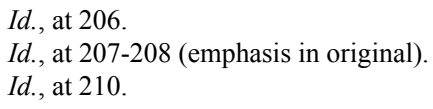


"understood as the organization of the energies and activities of its subjects, and of the resources of its territory, for the achievement of a single, premeditated end". ${ }^{29}$ Nomocracy, on the other hand, consists in the belief that the role of the state is to enable certain interactions between individuals, regardless of the ends pursued by those individuals. ${ }^{30}$ We are now in a position to see what links Fuller and Oakeshott, namely, the idea that the rule of law relates citizens to one another in a nonteleological or non-instrumental manner via the mediation of the concept of a role (or what Oakeshott calls a persona). More specifically, for Oakeshott:

The expression "the rule of law", taken precisely, stands for a mode of moral association exclusively in terms of the recognition of the authority of known, non-instrumental rules (that is, laws) which impose obligations to subscribe to adverbial conditions in the performance of the self-chosen actions of all who fall within their jurisdiction ... Like all other modes of association it is an abstract relationship of personae - persons solely in respect of being alike and without exception the subjects of these obligations to one another. ${ }^{31}$

Thus, says Oakeshott, the rule of law is a mode of moral association. It is an abstract form of relationship insofar as it is a relationship not of persons but of persons occupying roles. And it is a form of moral relationship because it involves an obligation to subscribe to and obey certain non-instrumental rules, namely, laws. ${ }^{32}$

To sum up, I have drawn a distinction between conceptions of the rule of law that locate its virtue in its ability to guide conduct towards a particular end, and conceptions of the rule of law that locate its virtue in its ability to regulate the interactions between citizens regardless of the ends that they choose to pursue. The latter, I take it, is what Oakeshott

\footnotetext{
29 Michael Oakeshott, Lectures in the History of Political Thought (Exeter, UK: Imprint Academic, 2006), at 471.

30 According to Oakeshott, nomocracy takes government "1) to be the custodian of a system of legal rights and duties in the enjoyment and observation of which the subjects of the government may pursue their own chosen ends and purposes while still remaining a single association. 2) to be the custodian of the interests of the association in relation to other similar associations": id., at 483-84.

31 Michael Oakeshott, "The Rule of Law" in Michael Oakeshott, On History and Other Essays (Oxford: Basil Blackwell, 1983) 119, at 136.

32 This might lead one to suppose that the conception of the rule of law that Oakeshott is proposing is a thick one. But this seems to be a mistake, for as Oakeshott famously says, "the rule of law bakes no bread, it is unable to distribute loaves or fish (it has none), and it cannot protect itself against external assault, but it remains the most civilized and least burdensome conception of the state yet to be devised": id., at 164 .
} 
has in mind when he talks about the rule of law as a mode of moral association. This conception of the rule of law is, I think, a powerful and attractive one, for reasons mentioned above: it makes sense of the very plausible idea that the rule of law constrains the actions of individuals by virtue of the role occupied by those individuals, and it articulates a vision of the rule of law according to which it governs not only state actors, but also private citizens. And it is this conception of the rule of law that will enable me to discuss my main topic, which is whether the Supreme Court of Canada's principled approach to hearsay is compatible with the rule of law.

\section{EVIDENCE LAW AND HEARSAY}

What I would like to do now is turn to a recent criticism of the Supreme Court of Canada's hearsay jurisprudence. The criticism I have in mind is found in Colin Tapper's paper "The Law of Evidence and the Rule of Law". ${ }^{33}$ Tapper's conclusion on the relationship between the law of evidence and the rule of law is largely negative. According to him the law of evidence

seems to be developing in a way quite antithetic to the classic conception of the rule of law. This can be seen in the blurring of the distinction between the admissibility and the admission of pieces of evidence; and the readiness of the courts to reject rules, both statutory and common law, in favor of discretion, both explicit and implicit in the use of vague and imprecise terminology; and in insulation from appeal of decisions by trial judges. ${ }^{34}$

My argument will be simple. I will present Tapper's criticism, indicate the extent to which it relies on an instrumental conception of the rule of law, and then suggest that if Oakeshott's conception of the rule of law is adopted, Tapper's criticism loses much of its force. So let me turn to Tapper's argument.

Tapper begins with the particular theory of the rule of law. According to this theory the enterprise of law "can be regarded as one of governing human beings by the translation of moral values and prescriptions into justiciable rules, that is to say by rules which can be understood and applied both by those subject to them and by those applying them. It is an

\footnotetext{
33 Tapper, supra, note 1.

$34 \quad$ Id., at 67.
} 
exercise in particularization". ${ }^{35}$ The rule of law, in other words, involves articulating rules and applying them in concrete situations. But the rule of law will be observed only in so far as those rules are applied consistently and objectively. This leads Tapper to conclude that

to maintain the rule of law to its greatest extent, the input of the judiciary should be kept as close as possible to the minimum required to allow the system to function. In this sense it can aspire to be seen as government by law, and not by men; by articulated rules and not by some form of palm tree justice. ${ }^{36}$

In short, according to Tapper, the more input judges have into the criminal justice system - and in particular, into the criminal trial - the less likely it is that the rule of law will be upheld. This is so in part because the more input judges have into the criminal justice system the more difficult it will be to predict with certainty how individual rules will be applied and what the outcome of any particular application of those rules will be. Tapper continues:

[T] he most egregious example in the law of evidence in this respect is to be seen in the deliberate decision of the Supreme Court of Canada to abandon "categorical" approach to the hearsay rule, and to substitute an approach dubbed "principled". ${ }^{37}$

What is the principled approach to hearsay? Let me approach this question by first considering the basic rule of evidence, which holds that all relevant evidence is presumptively admissible. Hearsay statements constitute an exception to this rule. To see why, consider a definition: a statement constitutes hearsay where (1) it is made expressly or impliedly by A out of court; where (2) it is offered in court in order to prove the truth of its contents; but where (3) there is no opportunity to contemporaneously cross-examine A on the making of the statement. ${ }^{38}$ Now consider the rule: any such out-of-court statement is presumptively inadmissible. ${ }^{39}$ Why?

\section{Id \\ Id., at 68 . \\ Id., at 71 .}

"The essential defining features of hearsay are therefore the following: (1) the fact that the statement is adduced to prove the truth of its contents and (2) the absence of a contemporaneous opportunity to cross-examine the declarant": $R$. v. Khelawon, [2006] S.C.J. No. 57, [2006] 2 S.C.R. 787, at para. 35 (S.C.C.), per Charron J. [hereinafter "Khelawon"].

39 Really, then, the hearsay rule is not so much a rule of exclusion, but a rule of use: an out-of-court statement is hearsay, and so presumptively inadmissible, if it is sought to be introduced into evidence to establish the truth of its content. If, however, it is introduced into evidence for some other purpose then it is not properly characterized as hearsay, and so is presumptively admissible. 
Because the lack of contemporaneous cross-examination renders the statement untrustworthy. As Charron J. put it in Khelawon:

Our adversary system puts a premium on the calling of witnesses, who testify under oath or solemn affirmation, whose demeanour can be observed by the trier of fact, and whose testimony can be tested by cross-examination. We regard this process as the optimal way of testing testimonial evidence. Because hearsay evidence comes in a different form, it raises particular concerns. ${ }^{40}$

So we have a general rule: hearsay statements are presumptively inadmissible. But we also have exceptions to the hearsay rule (which is itself an exception to the basic rule of evidence). Historically, these exceptions were assessed using the categorical approach to hearsay according to which, if a hearsay statement falls within one of the traditional exceptions or categories then it may be admitted into evidence provided its probative value outweighs its prejudicial effects. ${ }^{41}$

The principled approach to hearsay overturned this familiar picture. The principled approach was first considered by the Supreme Court in R. v. Khan ${ }^{42}$ and R. v. Smith, ${ }^{43}$ was revisited in R. v. Starr ${ }^{44}$ and R. v. Mapara ${ }^{45}$ and has received its most extensive recent treatment in Khelawon. ${ }^{46}$ The principled approach derives from statements made by Wigmore in Wigmore on Evidence. There Wigmore said the following:

The needless obstruction to investigation of truth caused by the hearsay rule is due mainly to the inflexibility of its exceptions, to the rigidly technical construction of those exceptions by the courts, and to the enforcement of the rule when its contravention would do no harm, but would assist in obtaining a complete understanding of the transaction. ${ }^{47}$

Wigmore's suggestion was that the inflexibility of the exceptions could be remedied by focusing on criteria of necessity and reliability. The Supreme Court built on Wigmore's insights in Khan, Smith, Starr,

$40 \quad$ Supra, note 38 , at para. 35 .

41 The traditional exceptions or categories include statements against interest by non-parties, party admissions, dying declarations, and spontaneous statements.

42 [1990] S.C.J. No. 81, [1990] 2 S.C.R. 531 (S.C.C.) [hereinafter "Khan"].

43 [1992] S.C.J. No. 74, [1992] 2 S.C.R. 915 (S.C.C.) [hereinafter "Smith"]. [2000] S.C.J. No. 40, [2000] 2 S.C.R. 144 (S.C.C.) [hereinafter "Starr"].

45 [2005] S.C.J. No. 23, [2005] 1 S.C.R. 358 (S.C.C.) [hereinafter "Mapara"].

46 Supra, note 38. For a more recent discussion, see R. v. Baldree, [2013] S.C.J. No. 35, 2013 SCC 35 (S.C.C.).

47 John Henry Wigmore, Wigmore on Evidence, 3d ed. (Boston, MA: Little, Brown, 1940), vol. 5 , at para. 1427. 
Mapara and Khelawon to refashion the law of hearsay. The twin concepts of necessity and reliability are central to the Court's approach. Crossexamination is the preferred method by which the trustworthiness of a speaker or statement is assessed. As Charron J. put it in Khelawon, "our adversary system is based on the assumption that sources of untrustworthiness or inaccuracy can best be brought to light under the test of crossexamination. It is mainly because of the inability to put hearsay evidence to that test, that it is presumptively inadmissible". ${ }^{48}$ Reliable hearsay evidence is therefore evidence for which there is a substitute for crossexamination that would justify its admission. Very generally, if a hearsay statement fits one of the traditional exceptions, it is admissible provided that the exception itself complies with the requirements of the principled approach. If a hearsay exception is not relied upon, then the hearsay statement may be admissible provided the statement satisfies the principled approach, that is, provided the statement is necessary and reliable.

More particularly, according to the Supreme Court in Khelawon, the principled approach's governing framework for hearsay is as follows:

(a) Hearsay evidence is presumptively inadmissible unless it falls under an exception to the hearsay rule. The traditional exceptions to the hearsay rule remain presumptively in place.

(b) A hearsay exception can be challenged to determine whether it is supported by indicia of necessity and reliability, required by the principled approach. The exception can be modified as necessary to bring it into compliance.

(c) In "rare cases", evidence falling within an existing exception may be excluded because the indicia of necessity and reliability are lacking in the particular circumstances of the case.

(d) If hearsay evidence does not fall under a hearsay exception, it may still be admitted if indicia of reliability and necessity are established on a voir dire. ${ }^{49}$

The principal effect of the principled approach - especially clause (d) - is to allow some necessary and reliable hearsay statements to be admitted where they would not have been admissible under the traditional exceptions.

$48 \quad$ Khelawon, supra, note 38 , at para. 48 .

$49 \quad$ Id., at para. 42, citing Mapara, supra, note 45, at para. 15. 
With this account in hand, let me return to Tapper's criticism of the principled approach. Tapper in effect makes two complaints. First, he argues that using considerations of reliability and necessity to justify specific exceptions to the rule excluding hearsay is not the same as using the principled approach. Although particular exceptions may be justified because they permit necessary and reliable evidence to be admitted, allowing judges to assess necessity and reliability confers on them too much discretion. Similarly, Tapper suggests the Court was incorrect in assuming that considerations of necessity and reliability are the basis of Wigmore's explanation of exceptions to the rule. Tapper observes that "[w]hile it may be true that such considerations played their part in moulding the rule and its exceptions, it is quite another matter to abandon the lower level rules so moulded in favour of reversion to these concepts themselves". 50

Second, Tapper claims that because the terms and concepts employed by the principled approach "are vague and require elaboration in the context of each set of different facts" the epistemic values of predictability and certainty have been lost. As a result, Tapper concludes that the principled approach to hearsay is in tension with the rule of law. Again, this is because the rule of law requires that legal rules be general, and that their application be predictable, requirements that in Tapper's view the principled approach to hearsay cannot meet.

In my view, however, neither criticism withstands scrutiny. Let me begin with Tapper's complaint that the Court was wrong to rely on Wigmore in the manner it did. It seems to me that Tapper misrepresents the relation between the requirements of necessity and reliability and the traditional hearsay exceptions. The principled approach does not abandon what Tapper calls the "lower level rules" or traditional exceptions; to the contrary, if a putative hearsay statement fits into one of those rules or exceptions then according to the principled approach the statement ought to be received into evidence unless it is neither reliable nor necessary. The principled approach modifies, but does not abandon, the traditional exceptions. ${ }^{51}$ As Charron J. says in Khelawon, "the traditional rules of evidence reflect considerable wisdom and judicial experience. The modern approach has built upon their underlying rationale, not discarded it. ${ }^{, 52}$

\footnotetext{
50 Tapper, supra, note 1, at 72.

51 See, in particular, Starr, supra, note 44.

$52 \quad$ Khelawon, supra, note 38 , at para. 59.
} 
Second, the idea that the traditional exceptions must be unified by and therefore manifest some deeper principle makes both legal and theoretical sense. To see why, compare the situation with respect to hearsay to the situation in the law of negligence. In Donoghue v. Stevenson, the House of Lords was confronted with an argument that it ought to acknowledge a broader conception of the duty of care than had previously been recognized. In accepting that argument, Lord Atkin famously said the following: "At present I content myself with pointing out that in English law there must be, and is, some general conception of relations giving rise to a duty of care, of which the particular cases found in the books are but instances." ${ }^{53}$ The general conception in question was the neighbour principle, which Lord Atkin memorably glossed as follows:

The rule that you are to love your neighbour becomes in law, you must not injure your neighbour; and the lawyer's question, Who is my neighbour? receives a restricted reply. ... Who, then, in law is my neighbour? The answer seems to be - persons who are so closely and directly affected by my act that I ought reasonably to have them in contemplation as being so affected when I am directing my mind to the acts or omissions which are called in question. ${ }^{54}$

In short, in reaching their conclusion in Donoghue v. Stevenson, the House of Lords concluded that the various categories of negligence, if they were to make sense, must be unified by some underlying normative principle.

The argument of the Supreme Court in Khan, Smith, Starr and Khelawon that there must be some underlying concept shared by the traditional exceptions to the hearsay rule parallels the argument in Donoghue v. Stevenson. Tapper's complaint that it is a mistake to revert to these concepts themselves therefore seems odd. If the traditional exceptions are coherent as exceptions they must be linked together somehow, and Wigmore's indicia of necessity and reliability seem to do precisely that. Indeed, by articulating a general principle that unifies the traditional exceptions, the principled approach better meets the rule of law's desideratum of generality emphasized by Fuller, among others.

To this it might be objected that the foregoing misrepresents Tapper's complaint. ${ }^{55}$ According to this objection, Tapper's claim is not that the

\footnotetext{
53 Donoghue v. Stevenson, [1932] A.C. 562 at 580, [1932] All E.R. Rep. 1 (H.L.).

$54 \quad$ Id.

55 I am indebted here to discussion with Graham Mayeda.
} 
categorical exceptions cannot be unified but that it is better to have judges apply particular rules rather than broad principles. This objection holds that the application of those principles allows judges too much discretion and could be used to admit evidence that goes beyond the specific exceptions. Even though evidence is reliable and necessary there may be countervailing considerations against admitting certain classes of that hearsay evidence. It is difficult to know what to make of this complaint largely because an acknowledged consequence of the principled approach to hearsay is that statements that would have been inadmissible under the categorical approach may become admissible under the principled approach. Thus, to cite as a "countervailing consideration" the fact that some hearsay admitted under the principled approach would not have been admitted under the categorical approach is either questionbegging — this, after all, is the point of the principled approach — or irrelevant, since it does not reflect badly on the indicia of necessity and reliability. To be sure, there may be a concern that too much hearsay will be admitted on the principled approach because it will become too easy to meet the requirements of reliability and necessity. And perhaps this is Tapper's worry. But by the same token, one might worry that too much hearsay will be admitted if the categorical approach is adopted, since meeting one of the categorical exceptions is no guarantee that the statement in question is in fact trustworthy.

Tapper's second criticism is slightly different, although it is related to the preceding complaint. In brief, Tapper alleges that the adoption of the principled approach to hearsay is in tension with the rule of law on the grounds that it has, in his terminology, "thrown the whole of Canadian law in this area into the melting pot" ${ }^{56}$ By this Tapper means that the appeal to flexible and general concepts such as necessity and reliability has taxed the resources of the courts. It has resulted in an enormous increase in litigation and required courts to hold a voir dire whenever a question of the admissibility of a hearsay statement arises on the principled approach. The objection, in short, is that the principled approach to hearsay is inconsistent with the rule of law because it makes the law more difficult to understand and apply, and because the considerations on which the principled approach is based, although appropriately general,

56 Tapper, supra, note 1 , at 72 . 
require giving too much power to judges. ${ }^{57}$ What are we to make of this criticism?

It seems to me that the criticism is only as good as the particular vision of the rule of law on which it rests. Tapper's concern seems mainly to be about the costs that the principled approach imposes when those principles are applied to particular situations. His worry is that the principled approach makes disagreement more likely because judges will admit contentious evidence that appears to satisfy the general principles and that such disagreement makes the criminal process more protracted and burdensome. To the extent that the rule of law is designed to particularize rules and principles, to turn "moral values and prescriptions into justiciable rules", this may very well be a concern. But it is a concern only if we accept an instrumental conception of the rule of law that locates its virtue in efficiency, clarity and justiciability. ${ }^{58}$ If instead we view the rule of law as an abstract form of moral association, then the fact that a legal institution or rule imposes costs of a certain kind on participants should be irrelevant. The concern should instead be whether the law of hearsay evidence is compatible with the normative ideal expressed by the rule of law.

These observations are somewhat defensive, amounting to the claim that for all that Tapper has argued, the principled approach to hearsay may be compatible with the rule of law. But can a positive argument be given for the conclusion that the principled approach and the rule of law are compatible? I believe it can. According to the picture I am sketching, the rule of law governs interactions between individuals by virtue of the roles they occupy. And some of the roles occupied by individuals in the criminal trial are those of judge, juror, accused, witness and victim. With this in mind, consider how a judge might approach the question whether to allow a hearsay statement $S$ to be introduced into evidence against an accused. If the judge admits $\mathrm{S}$ into evidence without the benefit of cross-examination or without engaging in a voir dire to determine whether $\mathrm{S}$ is necessary and reliable, she is displaying a lack of respect for the accused. By admitting $S$ the judge is expressing the view that certain concerns of the accused - that he not be wrongly labelled or stigmatized as a criminal, or have his liberty unjustly curtailed, for example — can be treated in a less than cautious

57 Says Tapper, the principles "exist at such a high level of generality that they can easily be agreed upon in advance, but at the expense of potential disagreement at the point of their application to particular situations": id., at 73.

$58 \quad$ See again Raz, supra, note 14. 
manner. On the other hand, by engaging in a voir dire to determine whether $\mathrm{S}$ is necessary and reliable the judge shows concern for the accused by ensuring that $\mathrm{S}$, which might reflect detrimentally on the accused, meets a threshold of trustworthiness. But such displays of concern and respect are precisely what the rule of law, understood as a form of moral association, demands: it requires individuals to treat individuals in particular ways based on the roles that they happen to occupy.

By way of further unpacking the foregoing let me return to a consideration of what the hearsay rule is designed to do. At a minimum, it is designed to exclude certain forms of otherwise relevant evidence, and thereby guard against the inclusion of unreliable evidence in the trial process. If the trial is a search for the truth, and if unreliable evidence is admitted into the record, then it is more likely that the search for truth will be compromised. Indeed, if we recall Wigmore's remarks, quoted above, this would seem to be the perspective adopted by him: what the inflexibility of the hearsay rule results in is the "needless obstruction to investigation of truth".

This perspective is clearly that of the external systems engineer. It views the trial from an epistemic perspective, and evaluates particular rules based on their epistemic value. But as we have seen, another perspective is available: the internal perspective of the fact-finder as a moral agent. From this perspective the trial is an attempt to reach a just verdict in a manner that respects justice. What does this require? At a minimum, it requires that judges adopt a stance of respect towards the accused. ${ }^{59}$ As Ho puts it: "The court cares to know the truth about an allegation because it cares about the party to whom acceptance of the allegation is harmful. The degree of caution it exercises in accepting the allegation is reflective of the measure of respect and concern it has for that person." 60

When a judge makes a determination of fact, or in her role as trier of law instructs the trier of fact on the proper interpretation of a legal rule or principle, she must always keep in mind that any ultimate conclusions that are reached are reached on the basis of inferences. It is true that the inferences in question are often to conclusions regarding matters of fact

59 For a similar perspective on the rules of evidence and the trial process, see again Stewart, supra, note 6. As Stewart puts it, "the rules of evidence and procedure for the criminal trial in a rightful condition cannot be designed solely to reach an outcome, or to satisfy the public's desire for a reassuring narrative of righting wrong or restoring order, or even to find out the truth - though they may indeed achieve all of these purposes - but they must also be consistent with the rights of the participants": id., at 180 .

60 Ho, supra, note 7 , at 282-83. 
concerning whether an accused did the things that he is claimed to have done. But because such inferences lead to conclusions that can have serious consequences for the accused, including deprivation of liberty, they also have normative implications. Hearsay statements highlight this problem starkly. When a hearsay statement is offered into evidence, its content is accepted as true, and on that basis the trier of fact is asked to accept the truth of some further proposition. But such an inference must be approached cautiously, given what is at stake. In preventing certain forms of relevant evidence from being considered by the trier of fact, the hearsay rule may compromise the truth-finding function of the criminal trial. At the same time, however, it ensures that any conclusion regarding the imposition of punishment on a particular accused will be adequately justified in light of the important interests involved. A conception of the rule of law as a form of moral association reflects this idea. Triers of law and triers of fact must do their best to ensure that any verdict reached is morally justified, and that in reaching a verdict the moral status of the affected individual is adequately respected. And to do this is to enter into a relationship that is both abstract - applying to individuals by virtue of the roles that they occupy - and moral, in the sense that it requires the adoption of a certain ethical stance with respect to individuals on whom the state is seeking to impose punishment. And my claim is that this is nothing more than Oakeshott's conception of the rule of law understood as a form of moral association.

To this it might be objected that this analysis is entirely too abstract. For even if Oakeshott's conception of the rule of law justifies the rule that hearsay statements should be admitted cautiously if at all, it might be argued that it does not explain why the principled approach in particular is to be preferred to the categorical approach that it seeks to displace. Two things are worth noting here. First, I have provided some reasons for thinking that the principled approach to hearsay constitutes an improvement over the categorical approach. These reasons are based not on the rule of law, but on the fact that the principled approach unifies, using the indicia of reliability and necessity, categories and exceptions that might initially seem to be distinct. And this, it seems to me, is a step forward in understanding the basis of the hearsay rule. But second, and more to the point, explaining why the principled approach is preferable to the categorical approach from the perspective of the rule of law is no part of my argument. If I am right that in dealing with hearsay, triers of law and triers of fact must adopt an appropriate ethical stance towards affected individuals, and if this ethical stance is consistent with the categorical 
approach, then there would seem to be no rule of law objection to adopting the categorical approach.

\section{CONCLUSION}

My goal in this paper has been to show that an attractive and plausible conception of the rule of law is consistent with the principled approach to hearsay. I argued against Colin Tapper's criticism of the principled approach by demonstrating that it rests on an instrumental concept of the rule of law. I then suggested that if we adopt Michael Oakeshott's normative conception of the rule of law, the principled approach to hearsay can be reconciled with it. This is not to say that only the principled approach to hearsay is consistent with the rule of law thus understood; there may be other ways to structure the hearsay inquiry that would also conform to this interpretation of the rule of law. But it does show that appeals to the virtues of efficiency and justiciability do not show that the principled approach to hearsay is deficient from the perspective of the rule of law.

In the background of this argument lie several other claims: that the primary purpose of the criminal trial is normative rather than epistemic; that an internal perspective on the criminal trial - which views judges as role-players within a system, and procedural and evidential rules as expressing normative principles - is preferable to an external perspective, which views the trial as primarily an epistemic tool designed to ferret out the truth; and that to judge requires the adoption of a particular ethical stance towards the participants in the trial process. These claims form a package of sorts. For they emphasize that when thinking about the criminal trial we must not lose sight of the fact that we are judging persons, and that somebody's being a person, and occupying a particular role in the criminal process, requires us to treat that individual in certain ways. The principled approach to hearsay can be complicated and unwieldy. But in its insistence that hearsay be admitted only when it meets the twin criteria of necessity and reliability it emphasizes the importance of reaching just verdicts in a manner that reflects justice. Courts fail to respect the accused if they use an out of court statement as the foundation of an inference that adversely affects the accused without ensuring that the statement or its maker is trustworthy. To do so is to treat this particular inference as one that can be made in an incautious and casual manner. And that is not a manifestation of the rule of law, but an exception to it. 
